\title{
Business Maturity Models for Small and Medium-Sized Enterprises: A Systematic Literature Review
}

\author{
PEETU VIRKKALA \\ University of Oulu, Finland \\ peetu.virkkala@oulu.fi \\ MARTTI SAARELA \\ University of Oulu, Finland \\ martti.saarela@oulu.fi \\ KAI HÄNNINEN \\ University of Oulu, Finland \\ kai.hanninen@oulu.fi \\ JAAKKO KUJALA \\ University of Oulu, Finland \\ jaakko.kujala@oulu.fi \\ ANNA-MARI SIMUNANIEMI \\ University of Oulu, Finland \\ anna-mari.simunaniemi@oulu.fi
}

Small and medium-sized enterprises (SMEs) play a key role in national economies around the world but face pressure to sustain their competitiveness in domestic and global markets. SMES should check their position periodically and figure out what they need to do next. Maturity models are suitable tools for documenting SMEs' current state, for developing the company's future vision and path and for comparing capabilities between companies. This study's aim is to obtain an overview of existing maturity models focused on SMEs by conducting a systematic literature review (SLR) of the publications on business maturity models from the lens of SmEs. As a result of this study, a growing trend for business maturity models for SMEs is identified and future research opportunities for SME maturity research are suggested.

Key words: smes, maturity model, business maturity model, systematic literature review

(c) BY-SA https://doi.org/10.26493/1854-4231.15.137-155

\section{Introduction}

Small and medium-sized enterprises (SMEs) play a key role in national economies around the world, generating employment, adding 
value and contributing to innovation (Organisation for Economic CoOperation and Development 2017). smes represent a major part of most modern economies and form the backbone of countries' national economies (European Commission 2011; Saarela et al. 2015; Storey 2014). Due to global competition, technological advances and consumers' changing needs, SMEs are under tremendous pressure to sustain their competitiveness in domestic and global markets (Singh, Garg, and Deshmukh 2008). More than large companies, smes face resource constraints in terms of finance, information, management capacity, etc. (Hollenstein 2005) and they have fewer human resources than larger firms to screen the external environment for valuable information (Spithoven, Vanhaverbeke, and Roijakkers 2013).

As a standard international definition of SME does not exist, this study uses the definition from the Organisation for Economic CoOperation and Development (2017), which refers to SMES as firms employing up to 249 persons. Like other enterprises, SMES should check periodically how they are fulfilling their growth goals to determine if they should change their business behaviour to reach those goals (Lent and Brown 2006). As mapping the developmental stage of businesses is complicated, business maturity models usually focus on a single aspect of business (Naskali et al. 2018), and assessment is often done using different kinds of maturity models that measure a company's ability for continuous improvement (Fraser, Moultrie, and Gregory 2002). There are comprehensive reviews of business maturity models for example related to business process management (Röglinger, Pöppelbuß, and Becker 2012; Tarhan, Turetken, and Reijers 2016), software processes (von Wangenheim et al. 2010), project management (Backlund, Chronéer, and Sundqvist 2014), process improvement (Helgesson, Höst, and Weyns 2012) and information systems (Mettler, Rohner, and Winter 2010). However, reviews of business maturity models for SMes are lacking. We aim to obtain an overview of the existing business maturity models for SMEs by answering the following research question:

What are the existing business maturity models for SMES and what do they focus on?

To answer this question, this article reviews what kind of business maturity models for SMES are currently offered in the literature in order to estimate the need for new models. This review is performed by conducting a systematic literature review (SLR) on business maturity models for SMES.

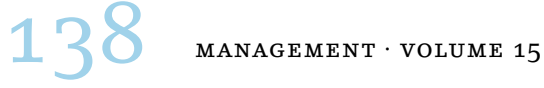




\section{Maturity Models}

Maturity models 'typically represent theories about how an organization's capabilities evolve in a stage-by-stage manner along an anticipated, desired, or logical path' (Röglinger, Pöppelbuß, and Becker 2012 , 4). Practitioners' adoption of maturity models and researchers' academic interest in maturity models have been increasing (Becker, Knackstedt, and Pöppelbuß 2009). Nowadays, the market is replete with different types of maturity and growth models that are designed to be used in general or specific business fields. Due to changes in the business environment, the need for specific models has increased in the SME business field (Saarela et al. 2018). Maturity models may help to determine where smes stand and figure out what they need to do next. Since the widely used and popular Capability Maturity Model (смм) was launched by the Software Engineering Institute over two decades ago (Paulk et al. 1993), hundreds of maturity models have been proposed by practitioners and researchers across multiple domains (Naskali et al. 2018; Pöppelbuß and Röglinger 2011). Maturity models have a long history and models are developed for various purposes. Many maturity models have also been developed by consultants and associations (e.g., Anderl et al. 2015; Felch, Asdecker, and Sucky 2019). Maturity model research has been applied in more than 20 domains, but it is still heavily dominated by software development and software engineering models (Wendler 2012).

According to Mettler, Rohner, and Winter (2010, 334), 'maturity implies evolutionary progress in the demonstration of a specific ability or in the accomplishment of a target from an initial to a desired or normally occurring end stage.' Maturity models divide evolutionary progress into a sequence of levels or stages that form a logical path from an initial state to a final level of maturity (Becker, Knackstedt, and Pöppelbuß 2009; Mettler, Rohner, and Winter 2010). These levels and stages are used in maturity models to derive and prioritise improvement measures and control the progress of change (Iversen, Nielsen, and Norbjerg 1999).

(De Bruin et al. 2005) have identified descriptive, comparative and prescriptive purposes for developing a maturity model. Becker, Knackstedt, and Pöppelbuß (2009), De Bruin et al. (2005), Iversen, Nielsen, and Norbjerg (1999), Maier, Moultrie, and Clarkson (2009) and Pöppelbuß and Röglinger (2011) clarified that maturity models serve a descriptive purpose if they are applied for 'as-is' assessments where the current capabilities of the entity under investigation are

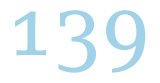


assessed with respect to given criteria, a comparative purpose if they allow for internal or external benchmarking and the maturity levels of similar business units and organisations can be compared, or a prescriptive purpose if they indicate how to identify desirable maturity levels and provide guidelines on improvement measures.

Business maturity models provide information about a company's current status and how to improve it (Röglinger, Pöppelbuß, and Becker 2012) and offer a simple but effective tool to measure companies' capabilities and contribute to transformation and the development of competencies in companies by initiating a change process (Mettler, Rohner, and Winter 2010; Wendler 2012). They can also be used in developing a company's future vision and path, as benchmarking tools to compare firms with each other to set development goals or as self-review frames and managerial tools for selfimprovement action (Felch, Asdecker, and Sucky 2019; Leino et al. 2017; Röglinger, Pöppelbuß, and Becker 2012). Many business maturity models have roots in смм (Paulk et al. 1993; Wendler 2012), and have adopted смм's five-level approach (level 1 - initial, level 2 - managed, level 3 -defined, level 4 - quantitatively managed and level 5 - optimised), which describes an evolutionary path of increasingly organised and systematic maturity stages.

Business maturity models are either generic or specific maturity models. Generic maturity models can be applied generally, whereas specific maturity models are designed and applied mainly to a specific business type (Blondiau, Mettler, and Winter 2016). Moreover, business maturity models can be classified based on the business type targeted. (Jones, Muir, and Beynon-Davies 2006) noted that three main business types are identified within the models: SMEs, large enterprises and non-specific companies.

Business maturity models have also been subject to criticism. For instance, they have been characterised as 'step-by-step recipes' that simplify business reality (Pöppelbuß and Röglinger 2011). Maturity models have faced questions on their lack of empirical foundation and validity (Lasrado, Vatrapu, and Andersen 2015; Mettler 2011; Pöppelbuß and Röglinger 2011). Researchers have criticised maturity models for differing quality: for instance, Mettler (2011) states that most maturity models are based on 'good practice' or 'success factors' derived from projects that have demonstrated favourable results. (Lasrado, Vatrapu, and Andersen 2015) observed that empirically validated maturity models are quite rare. According to these criticisms, models have mistaken structural assumptions (Lasrado, Vatrapu, and Andersen 2015), and they tend to neglect the potential

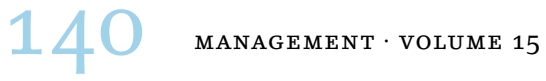


existence of multiple equally advantageous development paths (Teo and King 1997). Further criticism refers to narrow design methods, unsatisfactory documentation of the design process, the many almost identical maturity models and a non-reflective adoption of the смм approach (Becker, Knackstedt, and Pöppelbuß 2009; Iversen, Nielsen, and Norbjerg 1999; Lasrado, Vatrapu, and Andersen 2015; Mettler 2011; Pöppelbuß and Röglinger 2011). According to criticism, maturity models should not focus on a series of levels toward a predetermined 'final state' but on the factors that influence evolution and change (King and Kraemer 1984; Naskali et al. 2018).

\section{Systematic Literature Review to Identify Maturity Models in SME Context}

SLRS are well suited to identify gaps in the literature, generate recommendations for future research and reduce selection and data extraction bias (Grant and Booth 2009). Selection bias (when the author chooses only the research material which is consistent with their personal research goals and opinions) is minimised by defining clear inclusion and exclusion criteria for the literature review prior to the literature review (Liberati et al. 2009). Data extraction bias (when the author takes too much or too little data from included studies) is minimised by extracting research findings with a standardised form and reviewing them with a minimum of two reviewers (Nightingale 2009; Liberati et al. 2009).

According to Armstrong et al. (2011, 147), 'Systematic reviews use a transparent and systematic process to define a research question, search for studies, assess their quality and synthesise findings qualitatively or quantitatively.' sLRs are based on clearly formulated research questions, appraise the quality of reviewed literature and identify relevant literature systematically according to specific criteria to give an unbiased and balanced summary of the literature around the topic (Khan et al. 2003). SLRs' advantage over traditional literature reviews is their explicit presentation of the method of search, appraisal, synthesis and analysis of the literature (Grant and Booth 2009).

\section{Systematic Literature Review Method}

We first examined high-quality entrepreneurship-related peer-reviewed journals to identify best practices to include in the SLR. The 'Association of Business Schools Academic Journal Quality Guide' (https://charteredabs.org/academic-journal-guide-2018-view/), and the 'Australian Business Deans Council Journal Rankings List' (https:

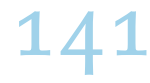


TABLE 1 SLR Method

\begin{tabular}{ll}
\hline Step & Description \\
\hline 1 Justifying the use of SLR & $\begin{array}{l}\text { Choice of the SLR over the traditional maturity model } \\
\text { is decided. } \\
\text { Research material and database focus are defined. } \\
\text { 2 SLR scope }\end{array}$ \\
K Search argument & $\begin{array}{l}\text { Keywords used and other search arguments are de- } \\
\text { fined. } \\
\text { A systematic search is conducted according to set } \\
\text { practices to identify the group of articles. }\end{array}$ \\
5 Systematic search & $\begin{array}{l}\text { A classification process is used to modify the group of } \\
\text { articles. } \\
\text { Comparable data is extracted and summarised in ma- } \\
\text { trix format. }\end{array}$ \\
\hline
\end{tabular}

//abdc.edu.au/research/abdc-journal-list/2016-interim-review) were used to identify high-quality peer-reviewed entrepreneurship journals. Five high-quality journals were selected: Small Business Journal, Journal of Small Business Management, Journal of Business Venturing, Entrepreneurship and Regional Development, Entrepreneurship, Theory and Practice. SLR articles from these journals was read, and findings from them were used together with SLR background knowledge to define the SLR method for this article (table 1). This step-by-step SLR method is described in the following section.

\section{JUSTIFYING THE USE OF SLR (STEP 1)}

As described, sLRs help give an unbiased and more balanced summary of the literature compared to traditional literature reviews. SLRS are well suited to identify gaps in the literature, generate recommendations for future research and reduce selection and data extraction bias, which may occur when large datasets are processed. Finally, SLRS increase the reliability of the literature review and make it more transparent for future studies. With these factors in mind, the use of SLR over the traditional literature review method felt well-grounded, and we decided to use SLR.

SLR SCOPE (STEP 2)

A clear focus for the research material and the databases to be used was set to minimise selection bias and increase the SLR's transparency. The scope of the SLR was business articles written in English with a business focus and published in peer-reviewed journals, as they are recognised as well-validated knowledge that is more likely to have a bigger impact in scientific research than articles

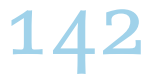


published in other sources (Podsakoff et al. 2005). The research databases selected to identify articles were Scopus and the Web of Science, which are considered to be among the most extensive academic databases for scientific knowledge (Guz and Rushchitsky 2009). Subject area filters were decided for both databases to narrow the search to the business field. In Scopus, the subject area 'Business, Management and Accounting' was used, whereas in Web of Science the subject area 'Business \& Economic' was used.

SEARCH ARGUMENT (STEP 3)

The keywords used and the search processes were defined step by step. As a starting point, the search was narrowed first to article titles and abstracts. Test searches were first conducted in Scopus with test keywords to get a better understanding of the topic. The conjunction 'OR' was used between keywords in the test search lists and the wildcard character ' $*$ ' was used at the end of each keyword to take different words with the same stem into account.

Distinct topic groups were then defined to group similar keywords together to simplify the search process. This led to the creation of two topic groups: 'maturity-related' and 'sme-related.' Keywords from the test searches were divided into these topic groups. If the keyword did not fit one of the topic groups, it was discarded. The topic groups were then used together in the following test searches by using the conjunction 'AND' between topic groups and 'OR' between keywords in the topic group as before. After some followup searches and changes in topic groups, the final versions of topic groups are defined in table 2 .

\section{SYSTEMATIC SEARCH (STEP 4)}

The topic group pair used to conduct the final search in Scopus and Web of Science found 162 articles in the 'Business, Management and Accounting' subject area in Scopus and 18 articles in the 'Business $\&$ Economic' subject area in the Web of Science. Eleven duplicate articles were removed from the search results, leaving 169 articles. Nine articles that were not in English or that were conference papers were removed, leaving 160 articles.

CLASSIFICATION PROCESS (STEP 5)

The classification process introduced by Thorpe et al. (2005) was used to limit the article group only to the articles that proposed a new maturity model in the SME context. The articles were assigned into three groups, according to set classification criteria: relevant studies 
TABLe 2 Chosen Topic Groups

\begin{tabular}{|c|c|c|}
\hline Topic group & Description & Keywords \\
\hline $\begin{array}{l}\text { Maturity- } \\
\text { related }\end{array}$ & $\begin{array}{l}\text { Topic group that includes } \\
\text { maturity related } \\
\text { terminology }\end{array}$ & $\begin{array}{l}\text { maturity model, maturity matrix, } \\
\text { maturity grid, maturity framework, } \\
\text { maturity level }\end{array}$ \\
\hline smE-related & $\begin{array}{l}\text { Topic group that includes } \\
\text { company related } \\
\text { terminology }\end{array}$ & $\begin{array}{l}\text { micro-company, micro-enterprise, } \\
\text { micro-firm, micro-business, } \\
\text { microcompany, microenterprise, } \\
\text { microfirm, microbusiness, micro } \\
\text { company, micro enterprise, micro firm, } \\
\text { micro business, small firm, small } \\
\text { business, small organisation, small } \\
\text { organization, small enterprise, sme, } \\
\text { small and medium-sized enterprise, } \\
\text { small and medium-sized firm, small and } \\
\text { medium-sized organization, small and } \\
\text { medium-sized organisation }\end{array}$ \\
\hline
\end{tabular}

TABLE 3 Used Classification Process Step by Step

\begin{tabular}{ll}
\hline Phase of inclusion-exclusion process & Number of articles \\
\hline Before 1st classific. process & 160 \\
1st classific. process: A, B, C grouping & 62 (group A), 61 (group B) and 37 (group C) \\
1st classific. process: re-review & 67 (group A) and 93 (group C) \\
2nd classific. process: A, B, C grouping & 20 (group A), 3 (group B) and 44 (group C) \\
2nd classific. process: re-review & 20 (group A) and 47 (group C) \\
After 2nd classific. process & 20
\end{tabular}

(A), studies in which the relevance was still unclear (B) and nonrelevant studies $(\mathrm{C})$. When all the articles were assigned to these groups, articles in group B were re-reviewed and assigned either to group A or C, and articles in group A were taken forward to further review (Thorpe et al. 2005). We applied the classification process twice with multiple reviewers to minimise selection bias. During the first classification process, the articles' title and abstract were read and the articles were classified into groups $\mathrm{A}, \mathrm{B}$ and $\mathrm{C}$, according to the first classification criteria, which was 'title and/or abstract of the article includes SME and maturity perspective.' This left 67 articles in group $\mathrm{A}$.

During the second classification process, the group A articles' abstract and full text were read, and the articles were classified into groups $\mathrm{A}, \mathrm{B}$ and $\mathrm{C}$, according to the second classification criteria, which was 'according to the abstract or full text of the article, the article creates or refines a business maturity model for smes.' This 
TABLE 4 Article Comparison Matrix

\begin{tabular}{|c|c|c|c|c|}
\hline Reference & Name & Industry & Focus & Levels \\
\hline $\begin{array}{l}\text { Adrodegari } \\
\text { and Saccani } \\
(2020)\end{array}$ & $\begin{array}{l}\text { A maturity model for } \\
\text { the servitisation of } \\
\text { product-centric com- } \\
\text { panies }\end{array}$ & General & $\begin{array}{l}\text { Servitisation maturity } \\
\text { model for companies }\end{array}$ & 5 \\
\hline $\begin{array}{l}\text { Cataldo et al. } \\
(2020)\end{array}$ & $\begin{array}{l}\text { Towards an inte- } \\
\text { grated maturity } \\
\text { model of system and } \\
\text { e-business applica- } \\
\text { tions in an emerging } \\
\text { economy }\end{array}$ & General & $\begin{array}{l}\text { Integrated matu- } \\
\text { rity model of busi- } \\
\text { ness systems and e- } \\
\text { business applications }\end{array}$ & 3 \\
\hline $\begin{array}{l}\text { Batista et al. } \\
(2019)\end{array}$ & $\begin{array}{l}\text { Knowledge manage- } \\
\text { ment for food sup- } \\
\text { ply chain synergies-a } \\
\text { maturity level analy- } \\
\text { sis of sME companies }\end{array}$ & $\begin{array}{l}\text { Food man- } \\
\text { ufacturing }\end{array}$ & $\begin{array}{l}\text { SME knowledge man- } \\
\text { agement adoption } \\
\text { maturity model }\end{array}$ & 4 \\
\hline $\begin{array}{l}\text { Omotayo et al. } \\
(2019)\end{array}$ & $\begin{array}{l}\text { Systems thinking and } \\
\text { cMM for continuous } \\
\text { improvement in the } \\
\text { construction industry }\end{array}$ & Constructio & $\begin{array}{l}\text { Capability maturity } \\
\text { model (cMM) for SME } \\
\text { construction compa- } \\
\text { nies in Nigeria }\end{array}$ & 5 \\
\hline $\begin{array}{l}\text { Pirola, Cimini, } \\
\text { and Pinto } \\
\text { (2019) }\end{array}$ & $\begin{array}{l}\text { Digital readiness as- } \\
\text { sessment of Italian } \\
\text { smEs: a case-study } \\
\text { research }\end{array}$ & General & $\begin{array}{l}\text { Industry } 4.0 \text { digital } \\
\text { readiness maturity } \\
\text { model for SMES }\end{array}$ & 5 \\
\hline $\begin{array}{l}\text { Parra et al. } \\
(2019)\end{array}$ & $\begin{array}{l}\text { A maturity model } \\
\text { for the information- } \\
\text { driven SME }\end{array}$ & General & $\begin{array}{l}\text { Information-driven } \\
\text { decision-making pro- } \\
\text { cess maturity model } \\
\text { for sMES }\end{array}$ & 5 \\
\hline $\begin{array}{l}\text { Andriani et al. } \\
(2018)\end{array}$ & $\begin{array}{l}\text { Aligning business } \\
\text { process maturity } \\
\text { level with SMES } \\
\text { growth in Indonesian } \\
\text { fashion industry }\end{array}$ & General & $\begin{array}{l}\text { Business process ma- } \\
\text { turity model for SMES }\end{array}$ & 5 \\
\hline $\begin{array}{l}\text { Isoherranen } \\
\text { and Ratnayake } \\
(2018)\end{array}$ & $\begin{array}{l}\text { Performance assess- } \\
\text { ment of microenter- } \\
\text { prises operating in } \\
\text { the Nordic Arctic re- } \\
\text { gion }\end{array}$ & General & $\begin{array}{l}\text { Operational excel- } \\
\text { lence maturity model } \\
\text { for microenterprises } \\
\text { in the Nordic Arctic } \\
\text { region }\end{array}$ & 5 \\
\hline
\end{tabular}

Continued on the next page

left 20 articles in group A, which formed the final article group. A summary of the classification criteria can be seen in table 3 .

DATA MATRIX (STEP 6)

To minimise data extraction bias, visualise the data and straightforwardly follow the analysis processes, comparable data was combined from the article group into a matrix form. Five categories reference, name, industry, focus and levels, were used to gather the data from the article pool. An article comparison matrix for the final article group is in table 4 . 
TABLE 4 Continued from the previous page

\begin{tabular}{|c|c|c|c|c|}
\hline Reference & Name & Industry & Focus & Levels \\
\hline $\begin{array}{l}\text { Igartua, Retegi, } \\
\text { and Ganzarain } \\
(2018)\end{array}$ & $\begin{array}{l}\text { IM2, a maturity model } \\
\text { for innovation in } \\
\text { SMES }\end{array}$ & General & $\begin{array}{l}\text { Innovation maturity } \\
\text { model tool for small } \\
\text { enterprises }\end{array}$ & 5 \\
\hline $\begin{array}{l}\text { Mamoghli, } \\
\text { Cassivi, and } \\
\text { Trudel (2018) }\end{array}$ & $\begin{array}{l}\text { Supporting business } \\
\text { processes through } \\
\text { human and Iт fac- } \\
\text { tors: A maturity } \\
\text { model }\end{array}$ & General & $\begin{array}{l}\text { Maturity model re- } \\
\text { lated to It and hu- } \\
\text { man factors which } \\
\text { improves companies' } \\
\text { business processes }\end{array}$ & 3 \\
\hline Prashar (2017) & $\begin{array}{l}\text { Energy efficiency } \\
\text { maturity (E EM) as- } \\
\text { sessment framework } \\
\text { for energy-intensive } \\
\text { smes: Proposal and } \\
\text { evaluation }\end{array}$ & General & $\begin{array}{l}\text { в м } \text { framework for } \\
\text { energy-intensive } \\
\text { SMES }\end{array}$ & 5 \\
\hline $\begin{array}{l}\text { Triandini, } \\
\text { Djunaidy, and } \\
\text { Siahaan (2017) }\end{array}$ & $\begin{array}{l}\text { A maturity model for } \\
\text { e-commerce adoption } \\
\text { by small and medium } \\
\text { enterprises in In- } \\
\text { donesia }\end{array}$ & General & $\begin{array}{l}\text { E-commerce maturity } \\
\text { model for Indonesia } \\
\text { SMES }\end{array}$ & 4 \\
\hline $\begin{array}{l}\text { Tontini et al. } \\
(2016)\end{array}$ & $\begin{array}{l}\text { Maturity model of } \\
\text { procurement and } \\
\text { supply manage- } \\
\text { ment in small and } \\
\text { medium-size enter- } \\
\text { prises: A benchmark- } \\
\text { ing of hospitals and } \\
\text { metal-mechanic com- } \\
\text { panies }\end{array}$ & General & $\begin{array}{l}\text { Procurement and } \\
\text { supply management } \\
\text { maturity model for } \\
\text { sMEs }\end{array}$ & 4 \\
\hline $\begin{array}{l}\text { Boonsiritomach } \\
\text { McGrath, and } \\
\text { Burgess (2016) }\end{array}$ & $\begin{array}{l}\text { aExploring business } \\
\text { intelligence and its } \\
\text { depth of maturity in } \\
\text { Thai smes }\end{array}$ & General & $\begin{array}{l}\text { Business intelligence } \\
\text { maturity model for } \\
\text { SMEs }\end{array}$ & 5 \\
\hline $\begin{array}{l}\text { Ganzarain and } \\
\text { Errasti (2016) }\end{array}$ & $\begin{array}{l}\text { Three stage maturity } \\
\text { model in SMEs to- } \\
\text { wards industry } 4.0\end{array}$ & General & $\begin{array}{l}\text { Industry } 4.0 \text { stage } \\
\text { process model for } \\
\text { companies }\end{array}$ & 5 \\
\hline
\end{tabular}

Continued on the next page

\section{Results}

The results were derived by combining knowledge from the article comparison matrix, the articles' full texts and the article analyses gathered from Scopus and the Web of Science. According to our findings, the article groupings revealed that the trend of SME business maturity model research has been growing steadily in recent years (table 5).

The articles' subject areas were compared in Scopus to identify what other subject areas were included in addition to business, management and accounting (table 6). Engineering, computer science and decision science were identified as the other most common sub- 
TABLE 4 Continued from the previous page

\begin{tabular}{|c|c|c|c|c|}
\hline Reference & Name & Industry & Focus & Levels \\
\hline $\begin{array}{l}\text { Powell, } \\
\text { Riezebos, and } \\
\text { Strandhagen } \\
(2013)\end{array}$ & $\begin{array}{l}\text { Lean production and } \\
\text { ERP systems in small- } \\
\text { and medium-sized } \\
\text { enterprises: ERP sup- } \\
\text { port for pull produc- } \\
\text { tion }\end{array}$ & General & $\begin{array}{l}\text { ERP system capabil- } \\
\text { ity maturity model for } \\
\text { SMES }\end{array}$ & 5 \\
\hline $\begin{array}{l}\text { Savino, Mazza, } \\
\text { and Ouzrout } \\
(2012)\end{array}$ & $\begin{array}{l}\text { PLM maturity model: } \\
\text { A multi-criteria as- } \\
\text { sessment in southern } \\
\text { Italy companies }\end{array}$ & $\begin{array}{l}\text { Electro- } \\
\text { mechanical }\end{array}$ & $\begin{array}{l}\text { PLM maturity model } \\
\text { based on an AHP } \\
\text { multi-criteria method } \\
\text { for SMES }\end{array}$ & 5 \\
\hline $\begin{array}{l}\text { Sinha et al. } \\
(2011)\end{array}$ & $\begin{array}{l}\text { Maturity measure- } \\
\text { ment of knowledge- } \\
\text { intensive business } \\
\text { processes }\end{array}$ & General & $\begin{array}{l}\text { Business process ma- } \\
\text { turity model for SMES }\end{array}$ & 5 \\
\hline $\begin{array}{l}\text { Plomp and } \\
\text { Batenburg } \\
(2010)\end{array}$ & $\begin{array}{l}\text { Measuring chain } \\
\text { digitisation maturity: } \\
\text { An assessment of } \\
\text { Dutch retail branches }\end{array}$ & Retail & $\begin{array}{l}\text { Chain digitisation } \\
\text { maturity model for } \\
\text { Dutch retail sector }\end{array}$ & 4 \\
\hline $\begin{array}{l}\text { Sturkenboom, } \\
\text { Van Der Wiele, } \\
\text { and Brown } \\
(2001)\end{array}$ & $\begin{array}{l}\text { An action-oriented } \\
\text { approach to quality } \\
\text { management self- } \\
\text { assessment in small } \\
\text { and medium-sized } \\
\text { enterprises }\end{array}$ & General & $\begin{array}{l}\text { Quality management } \\
\text { maturity model for } \\
\text { SMES }\end{array}$ & 5 \\
\hline
\end{tabular}

table 5 Publication Trend of Articles in the Article Group

\begin{tabular}{|c|c|c|c|c|c|c|c|}
\hline Year & Number & Year & Number & Year & Number & Year & Number \\
\hline 2001 & 1 & 2006 & 0 & 2011 & 1 & 2016 & 3 \\
\hline 2002 & 0 & 2007 & 0 & 2012 & 1 & 2017 & 2 \\
\hline 2003 & 0 & 2008 & 0 & 2013 & 1 & 2018 & 4 \\
\hline 2004 & 0 & 2009 & 0 & 2014 & 0 & 2019 & 4 \\
\hline 2005 & 0 & 2010 & 1 & 2015 & 0 & 2020 & 2 \\
\hline
\end{tabular}

ject area foci. Multiple articles emphasized the large role of smes in the economy (e.g., Batista et al. 2019; Isoherranen and Ratnayake 2018; Andriani et al. 2018). Many articles also agreed that there is a lack of maturity models developed for Smes (Sinha et al. 2011; Igar-

table 6 Trend of Article Publication in the sme Article Group

\begin{tabular}{ll}
\hline Subject area & Number of articles \\
\hline Engineering & 8 \\
Computer Science & 5 \\
Decision Science & 5 \\
Energy & 1 \\
Environmental Science & 1 \\
\hline
\end{tabular}


TABLE 7 Similarities Identified between the Analysed Maturity Models

\begin{tabular}{|c|c|}
\hline Grouping criteria & Description \\
\hline Digital focus & $\begin{array}{l}\text { Many maturity models had a digital theme. These included E- } \\
\text { business (Cataldo et al., 2020), business intelligence (Boon- } \\
\text { siritomachai, McGrath, and Burgess 2016), industry 4.o (Gan- } \\
\text { zarain and Errasti 2016; Pirola, Cimini, and Pinto 2019), ERP } \\
\text { (Powell, Riezebos, and Strandhagen 2013), PLM (Savino, } \\
\text { Mazza, and Ouzrout 2012) and IT (Mamoghli, Cassivi, and } \\
\text { Trudel 2018). }\end{array}$ \\
\hline смм focus & $\begin{array}{l}\text { There were two смM-based models: construction смM in } \\
\text { Omotayo et al. (2019) and ERP CMM in Powell, Riezebos, and } \\
\text { Strandhagen (2013). }\end{array}$ \\
\hline Holistic approach & $\begin{array}{l}\text { Many articles considered company aspects holistically in their } \\
\text { maturity models (e.g., Isoherranen and Ratnayake 2018; Igar- } \\
\text { tua, Retegi, and Ganzarain 2018; Sinha et al. 2011; Sturken- } \\
\text { boom, Van Der Wiele, and Brown 2001; Pirola, Cimini, and } \\
\text { Pinto 2019). }\end{array}$ \\
\hline Clear topic focus & $\begin{array}{l}\text { Some articles had a distinct topic of focus, including E- } \\
\text { commerce (Triandini, Djunaidy, and Siahaan 2017) and energy } \\
\text { efficiency (Prashar 2017). }\end{array}$ \\
\hline Supply chain focus & $\begin{array}{l}\text { Multiple articles had a supply chain focus in their maturity } \\
\text { models (e.g., Batista et al. 2019; Isoherranen and Ratnayake } \\
\text { 2018; Tontini et al. 2016). }\end{array}$ \\
\hline
\end{tabular}

tua, Retegi, and Ganzarain 2018; Triandini, Djunaidy, and Siahaan 2017; Tontini et al. 2016; Sturkenboom, Van Der Wiele, and Brown 2001). They felt that existing models had mainly been developed for larger companies and were either a bad fit for the SME context (Triandini, Djunaidy, and Siahaan 2017) or too complex for SMES (e.g., Sinha et al. 2011; Sturkenboom, Van Der Wiele, and Brown 2001; Adrodegari and Saccani 2020). Additionally, most of the articles addressed SME challenges in their business maturity models. In most cases, smes' limited resources were identified as the biggest challenge that should be considered when SME business maturity models are created (e.g., Adrodegari and Saccani 2020; Batista et al. 2019; Prashar 2017; Sinha et al. 2011; Plomp and Batenburg 2010). Furthermore, many articles identified small workforces (Batista et al. 2019; Omotayo et al. 2019), inadequate workforce experience (Adrodegari and Saccani 2020; Prashar 2017), and the complexity of the business topic (Pirola, Cimini, and Pinto 2019; Powell, Riezebos, and Strandhagen 2013; Omotayo et al. 2019) as challenges that should be considered when SME business maturity models are created.

Sixteen articles did not have a specific industry focus, whereas 
four articles had a clear industry focus. Moreover, there were no clear industry trends. Most of the articles $(n=14)$ used five maturity levels in their maturity models (e.g., Adrodegari and Saccani 2020; Omotayo et al. 2019). The remaining articles used either three, four or six maturity levels (e.g., Cataldo et al. 2020; Batista et al. 2019). The focus of the maturity models varied greatly between the articles. However, some other similarities were found between the articles, and they were grouped together (see table 7 ).

Nine articles incorporated a country or local area focus in their business maturity model, including: South America $(n=1)$, Africa $(n=1)$, Europe $(n=4)$ and Asia $(n=3)$. Some of these articles emphasised the differences in the SME maturity models between countries. Further, Omotayo et al. (2019) and Cataldo et al. (2020) highlighted the need for SME maturity models in the developing country context. Moreover, some of the articles argued that existing maturity models even in an SME context have been biased towards developed economies and thus cannot be applied in developed countries with good results (e.g., Cataldo et al. 2020; Triandini, Djunaidy, and Siahaan 2017).

\section{Discussion}

The goal of this article was to present an overview of existing business maturity models for SMEs and to learn more about their foci. This was achieved by conducting a SLR, which led to the identification of 20 articles that created or refined a business maturity model. These articles were then analysed to fulfil the goal of the present work. The analysis revealed that there is a growing trend of business maturity model research in the SME context. Existing SME business model research is diverse, but some similarities can be observed between the models. For example, there are many models that have a digital theme (e.g., Powell, Riezebos, and Strandhagen 2013; Mamoghli, Cassivi, and Trudel 2018). These findings are also consistent with the findings of Van Looy, Poels, and Snoeck (2017), who reported that maturity models typically focus on project management, knowledge management, business-Iт alignment, or specific process types, such as software processes.

According to our findings, limited resources, small workforces, inadequate workforce experience and topic complexity are the most common SME challenges that are addressed in SME business maturity research. Many articles described a lack of SME-focused maturity models and emphasized the SME focus in their models (e.g., Sinha et al. 2011; Igartua, Retegi, and Ganzarain 2018). Some of the articles 
highlighted the need to design more SME business maturity models specifically in the developing economy context (Omotayo et al. 2019; Cataldo et al. 2020). These findings open up many research opportunities for future studies. The results strongly suggest that there is still a need for SME-focused business maturity models. Future research could also expand into other types of maturity models to identify if there are similar trends in the bigger research context. Further exploration should be done to identify SME business maturity model differences between developing and developed countries to improve future models.

Based on the findings, the overarching concern is that there is a lack of micro-enterprise-focused maturity models. Despite the fact that micro-companies are the dominant sub-group of SME enterprises in the economy (Saarela et al. 2018), only five articles mentioned micro-enterprises (Andriani et al. 2018; Prashar 2017; Igartua, Retegi, and Ganzarain 2018; Tontini et al. 2016; Isoherranen and Ratnayake 2018), and only two articles considered micro-enterprises as a sub-group of SMEs in their business maturity models (Isoherranen and Ratnayake 2018; Igartua, Retegi, and Ganzarain 2018).

According to the authors, the SLR was designed and implemented successfully, but the need for improvement was also identified. Basic SLR practices were fulfilled; the SLR was based on a clear research question, the quality of the literature was reviewed, and the SLR process was systematically conducted step-by-step. Clear inclusionexclusion criteria were defined and followed in advance to minimize selection bias. Additionally, a matrix form was used to gather data systematically from the articles and was reviewed by multiple authors to minimize data bias. However, when the findings from the article group were identified, the full texts of the articles were still used to confirm some findings. Ideally, only the data in the matrixform should have been used to minimize data bias.

\section{References}

Adrodegari, F., and N. Saccani. 2020. 'A Maturity Model for the Servitization of Product-Centric Companies.' Journal of Manufacturing Technology Management 31 (4): 775-97.

Anderl, R., A. Picard, Y. Wang, J. Fleischer, S. Dosch, B. Klee, and J. Bauer. 2015. 'Guideline Industrie 4.0.' vD MA Forum Industrie 4:1-31.

Andriani, M., T. A. Samadhi, J. Siswanto, and K. Suryadi. 2018. 'Aligning Business Process Maturity Level with smes Growth in Indonesian Fashion Industry.' International Journal of Organizational Analysis 26 (4): 709-27.

Armstrong, R., B. J. Hall, J. Doyle, and E. Waters. 2011. '“Scoping the 
Scope" of a Cochrane Review.' Journal of Public Health 33 (1): 14750.

Backlund, F., D. Chronéer, and E. Sundqvist. 2014. 'Project Management Maturity Models: A Critical Review: A Case Study within Swedish Engineering and Construction Organizations.' Procedia-Social and Behavioral Sciences 119 (o): 837-46.

Batista, L., M. Dora, J. Toth, A. Molnár, H. Malekpoor, and S. Kumari. 2019. 'Knowledge Management for Food Supply Chain Synergies: A Maturity Level Analysis of sme Companies.' Production Planning and Control 30 (10-12): 995-1004.

Becker, J., R. Knackstedt, and J. Pöppelbuß. 2009. 'Developing Maturity Models for Iт Management: A Procedure Model and Its Application.' Business and Information Systems Engineering 1 (3): 213-22.

Blondiau, A., T. Mettler, and R. Winter. 2016. 'Designing and Implementing Maturity Models in Hospitals: An Experience Report from 5 Years of Research.' Health Informatics Journal 22 (3): 758-67.

Boonsiritomachai, W., G. M. McGrath, and S. Burgess. 2016. 'Exploring Business Intelligence and Its Depth of Maturity in Thai smes.' Cogent Business and Management 3 (1): 1220663.

Cataldo, A., C. A. Astudillo, J. H. Gutiérrez-Bahamondes, L. GonzálezMartínez, and R. McQueen. 2020. 'Towards an Integrated Maturity Model of System and E-Business Applications in an Emerging Economy.' Journal of Theoretical and Applied Electronic Commerce Research 15 (2): 1-14.

de Bruin, T., R. Freeze, U. Kulkarni, and M. Rosemann. 2005. 'Understanding the Main Phases of Developing a Maturity Assessment Model.' In Proceedings of the 16th Australasian Conference on Information Systems, 1-10. Sydney: AIs.

European Commission. 2011. 'Proposal for a Directive of the European Parliament and of the Council on Public Procurement.' сом(2011) 896 final 2011/0438 (COD) c7-0006/12 EN, European Commission, Brussels.

Felch, V., B. Asdecker, and E. Sucky. 2019. 'Maturity Models in the Age of Industry 4.0 - Do the Available Models Correspond to the Needs of Business Practice?' In Proceedings of the 52nd Hawaii International Conference on System Sciences, 5165-74. Honolulu, HI: University of Hawai'i at Manoa.

Fraser, P., J. Moultrie, and M. Gregory. 2002. 'The Use of Maturity Models/Grids as a Tool in Assessing Product Development Capability.' In IEE International Engineering Management Conference (IEMC 2002): Managing Technology for the New Economy, 244-9. Cambridge: IEEE.

Ganzarain, J., and N. Errasti. 2016. 'Three Stage Maturity Model in smes toward Industry 4.0.' Journal of Industrial Engineering and Management 9 (5): 1119-28.

Grant, M. J., and A. Booth. 2009. 'A Typology of Reviews: An Analysis of 
14 Review Types and Associated Methodologies.' Health Information and Libraries Journal 26 (2): 91-108.

Guz, A. N., and J. J. Rushchitsky. 2009. 'Scopus: A System for the Evaluation of Scientific Journals.' International Applied Mechanics 45 (4): 351-62.

Helgesson, Y. Y. L., M. Höst, and K. Weyns. 2012. 'A Review of Methods for Evaluation of Maturity Models for Process Improvement.' Journal of Software: Evolution and Process 24 (4): 436-54.

Hollenstein, H. 2005. 'Determinants of International Activities: Are smes Different?' Small Business Economics 24 (5): 431-50.

Igartua, J. I., J. Retegi, and J. Ganzarain. 2018. 'IM2, a Maturity Model for Innovation in smes.' Dirección y Organización 64:42-9.

Isoherranen, V., and R. C. Ratnayake. 2018. 'Performance Assessment of Microenterprises Operating in the Nordic Arctic Region.' Journal of Small Business and Entrepreneurship 30 (5): 431-49.

Iversen, J., P. A. Nielsen, and J. Norbjerg. 1999. 'Situated Assessment of Problems in Software Development.' Database for Advances in Information Systems 30 (2): 66-81.

Jones, P., E. Muir, and P. Beynon-Davies. 2006. 'The Proposal of a Comparative Framework to Evaluate E-Business Stages of Growth Models.' International Journal of Information Technology and Management 5 (4): 249-66.

Khan, K. S., R. Kunz, J. Kleijnen, and G. Antes. 2003. 'Five Steps to Conducting a Systematic Review.' Journal of the Royal Society of Medicine 96 (3): 118-21.

King, J. L., and K. L. Kraemer. 1984. 'Evolution and organizational Information Systems: An Assessment of Nolan's Stage Model.' Communications of the Aсм 27 (5): 466-75.

Lasrado, L. A., R. Vatrapu, and K. N. Andersen. 2015. 'Maturity Models Development in is Research: A Literature Review.' Paper presented at the 38th Information Systems Research Seminar in Scandinavia, Oulu, 9-12 August.

Leino, S.-P., O. Kuusisto, J. Paasi, and M. Tihinen. 2017. 'vт т Model of Digimaturity.' In Towards a New Era in Manufacturing: Final Report of vтт's for Industry Spearhead Programme, edited by J. Paasi, 41-6. Espoo: vтT.

Lent, R. W., and S. D. Brown. 2006. 'On Conceptualizing and Assessing Social Cognitive Constructs in Career Research: A Measurement Guide.' Journal of Career Assessment 14 (1): 12-35.

Liberati, A., D. G. Altman, J. Tetzlaff, C. Mulrow, P. C. Gøtzsche, J. P. Ioannidis, and D. Moher. 2009. 'The PRISMA Statement for Reporting Systematic Reviews and Meta-Analyses of Studies that Evaluate Health Care Interventions: Explanation and Elaboration.' PLos Medicine 6 (7): e1000100.

Naskali, J., J. Kaukola, J. Matintupa, H. Ahtosalo, M. Jaakola, and A. 
Tuomisto. 2018. 'Mapping Business Transformation in Digital Landscape: A Prescriptive Maturity Model for Small Enterprises.' In International Conference on Well-Being in the Information Society, 10116. Cham: Springer.

Nightingale, A. 2009. 'A Guide to sLrs.' Surgery 27 (9): 381-4.

Maier, A. M., J. Moultrie, and P. J. Clarkson. 2009. 'Developing Maturity Grids for Assessing Organisational Capabilities: Practitioner Guidance.' Paper presented at 4th International Conference on Management Consulting, Vienna, 1 January.

Mamoghli, S., L. Cassivi, and S. Trudel. 2018. 'Supporting Business Processes through Human and Iт Factors: A Maturity Model.' Business Process Management Journal 24 (4): 985-1006.

Mettler, T. 2011. 'Maturity Assessment Models: A Design Science Research Approach.' International Journal of Society Systems Science 3 (1-2): 81-98.

Mettler, T., P. Rohner, and R. Winter. 2010. 'Towards a Classification of Maturity Models in Information Systems.' In Management of the Interconnected World, edited by A. D'Atri, M. De Marco, A. M. Braccini, and F. Cabiddu, 333-40. Heidelberg: Physica-Verlag.

Omotayo, T. S., P. Boateng, O. Osobajo, A. Oke, and L. I. Obi. 2019. ‘Systems Thinking and смм for Continuous Improvement in the Construction Industry.' International Journal of Productivity and Performance Management 69 (2): 271-96.

Organisation for Economic Co-Operation and Development. 2017. 'Enhancing the Contributions of smes in a Global and Digitalised Economy.' https://www.oecd.org/industry/C-MIN-2017-8-EN.pdf

Parra, X., X. Tort-Martorell, C. Ruiz-Viñals, and F. Á. Gómez. 2019. 'Maturity Model for the Information-Driven SME.' Journal of Industrial Engineering and Management 12 (1): 154-75.

Paulk, M. C., B. Curtis, M. B. Chrissis, and C. V. Weber. 1993. 'Capability Maturity Model, Version 1.1.' Ife E Software 10 (4): 18-27.

Pirola, F., C. Cimini, and R. Pinto. 2019. 'Digital Readiness Assessment of Italian smes: A Case-Study Research.' Journal of Manufacturing Technology Management 31 (5): 1045-83.

Plomp, M. G., and R. S. Batenburg. 2010. 'Measuring Chain Digitisation Maturity: An Assessment of Dutch Retail Branches.' Supply Chain Management 15 (3): 227-37.

Podsakoff, P. M., S. B. MacKenzie, D. G. Bachrach, and N. P. Podsakoff. 2005. 'The Influence of Management Journals in the 1980 s and 1990s.' Strategic Management Journal 26 (5): 473-88.

Powell, D., J. Riezebos, and J. O. Strandhagen. 2013. 'Lean Production and ERP Systems in Small- and Medium-Sized Enterprises: ERP Support for Pull Production.' International Journal of Production Research $5^{1}(2)$ : 395-409. 
Pöppelbuß, J., and M. Röglinger. 2011. ‘What Makes a Useful Maturity Model? A Framework of General Design Principles for Maturity Models and Its Demonstration in Business Process Management.' Discussion Paper wI-327, University of Augsburg. https://fim-rc.de/ Paperbibliothek/Veroeffentlicht/327/wi-327.pdf

Prashar, A. 2017. 'Energy Efficiency Maturity (E EM) Assessment Framework for Energy-Intensive smes: Proposal and Evaluation.' Journal of Cleaner Production 166:1187-201.

Röglinger, M., J. Pöppelbuß, and J. Becker. 2012. 'Maturity Models in Business Process Management.' Business Process Management Journal 18 (2): 328-46.

Saarela, M., A. M. Simunaniemi, M. Muhos, and P. Leviäkangas. 2018. 'Growth Management of eHealth Service Start-Ups.' Journal of Advances in Management Research 15 (1): 17-36.

Saarela, M., O. Kauppila, E. R. Niinikoski, M. Muhos, and P. Leviäkangas. 2015. 'Public Advisory Services for Early-Stage Companies in Northern Sparsely Populated Area.' International Journal of Innovation and Regional Development 6 (4): 356-75.

Saarela, M., E. R. Niinikoski, M. Muhos, V. Isoherranen, and P. Leviäkangas. 2018. 'Small-and Medium-Sized Enterprises in Public Procurement in Primary Social and Healthcare Services.' International Journal of Procurement Management 11 (1): 76-95.

Savino, M. M., A. Mazza, and Y. Ouzrout. 2012. 'Plm maturity Model: A Multi-Criteria Assessment in Southern Italy Companies.' International Journal of Operations and Quantitative Management 18 (3): 159-80.

Singh, R. K., S. K. Garg, and S. G. Deshmukh. 2008. 'Strategy Development by smes for Competitiveness: A Review.' Benchmarking 15 (5): 525-47.

Sinha, M., R. Jochem, D. Geers, and P. Heinze. 2011. 'Maturity Measurement of Knowledge-Intensive Business Processes.' тQм Journal 23 (4): 377-87.

Spithoven, A., W. Vanhaverbeke, and N. Roijakkers. 2013. 'Open Innovation Practices in SMes and Large Enterprises.' Small Business Economics 41 (3): 537-62.

Storey, D. J. 1994. Understanding the Small Business Sector. London: Routledge.

Sturkenboom, J., T. Van Der Wiele, and A. Brown. 2001. 'An ActionOriented Approach to Quality Management Self-Assessment in Small and Medium-Sized Enterprises.' Total Quality Management 12 (2): 231-46.

Tarhan, A., O. Turetken, and H. A. Reijers. 2016. 'Business Process Maturity Models: A Systematic Literature Review.' Information and Software Technology 75:122-34.

Teo, T. S. H., and W. R. King. 1997. 'Integration between Business 
Planning and Information Systems Planning: An EvolutionaryContingency Perspective.' Journal of Management Information Systems 14 (1): 185-214.

Thorpe, R., R. Holt, A. Macpherson, and L. Pittaway. 2005. 'Using Knowledge within Small and Medium-Sized Firms: A Systematic Review of the Evidence.' International Journal of Management Reviews 7 (4): 257-81.

Tontini, G., L. C. de Carvalho, N. F. da Costa Schlindwein, and V. Tomarevski. 2016. 'Maturity Model of Procurement and Supply Management in Small and medium-Size Enterprises.' International Journal of Quality and Service Sciences 8 (3): 315-33.

Triandini, E., A. Djunaidy, and D. Siahaan. 2017. 'A Maturity Model for E-Commerce Adoption by Small and Medium Enterprises in Indonesia.' Journal of Electronic Commerce in Organizations 15 (1): 4458.

Van Looy, A., G. Poels, and M. Snoeck. 2017. 'Evaluating Business Process Maturity Models.' Journal of the Association for Information Systems 18 (6): 461-86.

Von Wangenheim, C. G., J. C. R. Hauck, C. F. Salviano, and A. von Wangenheim. 2010. 'Systematic Literature Review of Software Process Capability/Maturity Models.' Paper presented at the International Conference on Software Process Improvement and Capacity Determination, Pisa, 10 May.

Wendler, R. 2012. 'The Maturity of Maturity Model Research: A Systematic Mapping Study.' Information and Software Technology 54 (12): 1317-39. 